\title{
Enantiospecific synthesis of (-)-4-thiocyanatoneopupukeanane ${ }^{\dagger}$
}

\author{
A. Srikrishna* and Santosh J. Gharpure \\ Department of Chemistry, Indian Institute of Science, Bangalore 560012, India \\ E-mail: ask@orgchem.iisc.ernet.in
}

\begin{abstract}
Dedicated to Professor S. V. Kessar on the occasion of his $70^{\text {th }}$ birthday
(received 07 May 02; accepted 20 Jun 02; published on the web 28 Jun 02)
\end{abstract}

\begin{abstract}
Enantiospecific total synthesis of the natural enantiomer of the marine sesquiterpene (-)-4thiocyanatoneopupukeanane (6) is described. The bicyclo[2.2.2]octanonecarboxylate 11, obtained from $(R)$-carvone and methyl methacrylate via Michael-Michael reaction, was transformed into bicyclo[2.2.2] octenecarboxylic acid 8. Intramolecular cyclopropanation reaction of the diazo ketone $\mathbf{7}$, derived from the acid $\mathbf{8}$, followed by regioselective reductive cyclopropane ring cleavage generated neopupukeanol 20, which was transformed into (-)-4-thiocyanatoneopupukeanane $\mathbf{6}$.
\end{abstract}

Keywords: Carvone, marine sesquiterpenes, Michael-Michael reaction, intramolecular cyclopropanation reaction, regioselective cyclopropane ring cleavage

\section{Introduction}

In variety of marine organisms, chemical defense via secretion of toxic and/or strong smelling organic compounds from their skin glands is a common phenomenon as part of the self-defense mechanism to protect themselves from higher animals. Based on the observation that the nudibranch Phyllidia varicosa Lamarck secretes a toxic substance lethal to fish and crustaceans, Scheuer and coworkers investigated on the chemical constituents of the skin extracts of $P$. varicosa and also from its prey, a sponge Ciocalypta sp. These investigations led to the isolation ${ }^{1}$ of two isotwistane (1) based sesquiterpenes, 9- and 2-isocyanopupukeananes 2 and 3. Subsequently, during their biosynthetic experiments directed towards discovering the origin of the isocyano group in marine sponges, Scheuer and co-workers ${ }^{2}$ isolated a new sesquiterpene $\mathbf{4}$ from the sponge Ciocalypta sp. containing a new carbon framework neopupukeanane. Later the research groups of Scheuer and Higa reported ${ }^{3}$ the isolation of two thiocyanate containing sesquiterpenes, and assigned the structures as 2- and 4-thiocyanatoneopupukeananes $\mathbf{5 a}$ and $\mathbf{6}$, from the sponge Phycopsis terpnis (from Okinawa) and from an unidentified species from Pohnpei. Subsequently, Faulkner and co-

\footnotetext{
${ }^{\dagger}$ Chiral synthons from carvone, Part 56. For part 55, see reference (80).
} 
workers reported $^{4}$ the isolation of 2-thiocyanatoneo-pupukeanane 5b from Axinyssa aplysinoides from Palau, which was found to be identical to that isolated by Scheuer and Higa, and corrected the stereochemistry of the thiocyanate group as endo, on the basis of the 2D NMR spectra in $\mathrm{C}_{6} \mathrm{D}_{6}$. Biosynthetically, origin of pupukeananes and neopupukeananes can be explained by a common pathway via cyclization and rearrangement of cadinanes. ${ }^{2}$ It is interesting to note that very few $(<10)$ natural products have been reported to contain a thiocyanate group. Even though significant amount of synthetic activity ${ }^{5}$ was reported on the synthesis of pupukeananes, there was no report on the synthesis of neopupukeananes prior to $1998 .{ }^{6,7}$ In continuation of our interest in the enantiospecific synthesis of natural products, ${ }^{8}$ herein we describe the details ${ }^{6}$ of the enantiospecific total synthesis of 4-thiocyanatoneopupukeanane 6 starting from $(R)$-carvone employing an intramolecular cyclopropanation reaction based approach.

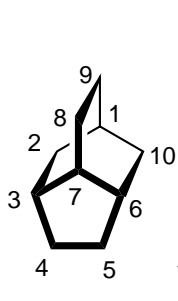

1

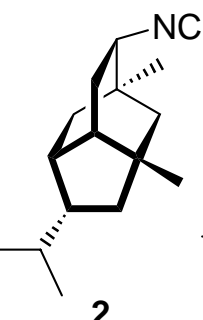

2

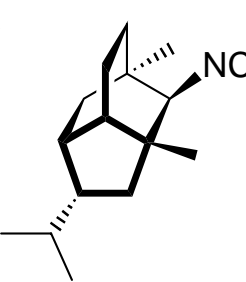

3

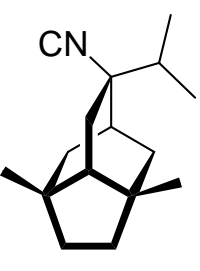

4

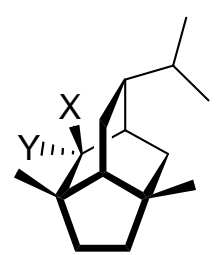

$5 \mathrm{a} X=\mathrm{SCN} ; \mathrm{Y}=\mathrm{H}$

5b. $X=\mathrm{H} ; \mathrm{Y}=\mathrm{SCN}$

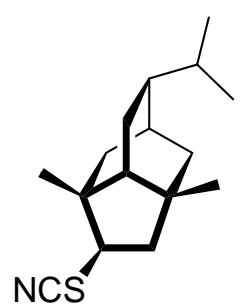

6

\section{Results and Discussion}

It was envisaged (Scheme 1) that the intramolecular cyclopropanation reaction of the diazo ketone 7, derived from bicyclo[2.2.2]octenecarboxylic acid $\mathbf{8}$, followed by cyclopropane ring cleavage would generate the isotwistanone $\mathbf{9}$ in a regioselective manner. Whereas, Michael-Michael reaction of $(R)$-carvone (10) with methyl methacrylate could be exploited for the generation of the bicyclo[2.2.2] octenecarboxylic acid 8.

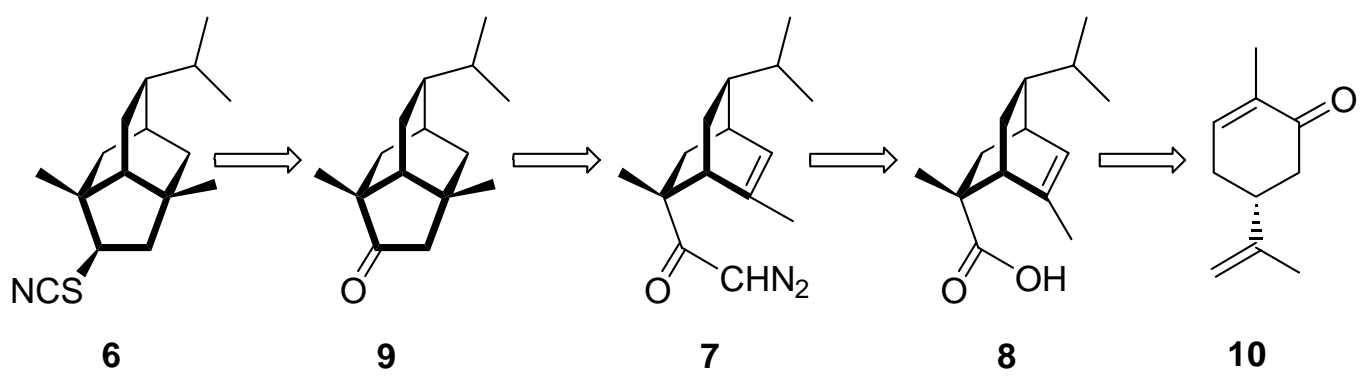

\section{Scheme 1}


The synthetic sequence is depicted in Scheme 2. Thus, reaction of $(R)$-carvone $\mathbf{1 0}$ with lithium hexamethyldisilazide (LiHMDS) in hexane at $-78^{\circ} \mathrm{C}$ followed by reaction of the resultant kinetic dienolate with one equivalent of methyl methacrylate furnished the bicyclic keto ester 11, m.p. 59-61 ${ }^{\circ} \mathrm{C}$ (lit. ${ }^{9}$ 60-61 ${ }^{\circ} \mathrm{C}$ ) via the Michael-Michael reaction in a highly regio- and stereoselective manner, which on catalytic hydrogenation generated the keto-ester 12. For the conversion of the keto group into olefin, reduction-methanesulfonylation-elimination protocol was contemplated. Thus, regioselective reduction of the keto ester 12 with sodium borohydride in methanol at $0{ }^{\circ} \mathrm{C}$ furnished the alcohol 13, m.p. 68-70 ${ }^{\circ} \mathrm{C}$. Methanesulfonylation reaction of the alcohol 13 with methanesulfonyl chloride in pyridine in the presence of a catalytic amount of DMAP followed by purification over a silica gel column furnished the mesylate 14, m.p. 67-69 ${ }^{\circ} \mathrm{C}$, in $60 \%$ yield. ${ }^{10}$ Treatment of the mesylate $\mathbf{1 4}$ with sodium ethoxide in refluxing THF-ethanol furnished the bicyclo[2.2.2]octenecarboxylic acid $\mathbf{8}$ in moderate yield. In another direction, in an attempt to reductively remove the methanesulfonate group to generate the alcohol 15, the methanesulfonate 14 was treated with an excess of lithium aluminium hydride (LAH) in refluxing THF, which resulted in the formation of the olefinic alcohol 16 in $80 \%$ yield, contrary to the expected alcohol $\mathbf{1 5}$. The structure of the alcohol $\mathbf{1 6}$ was derived from its spectral data.

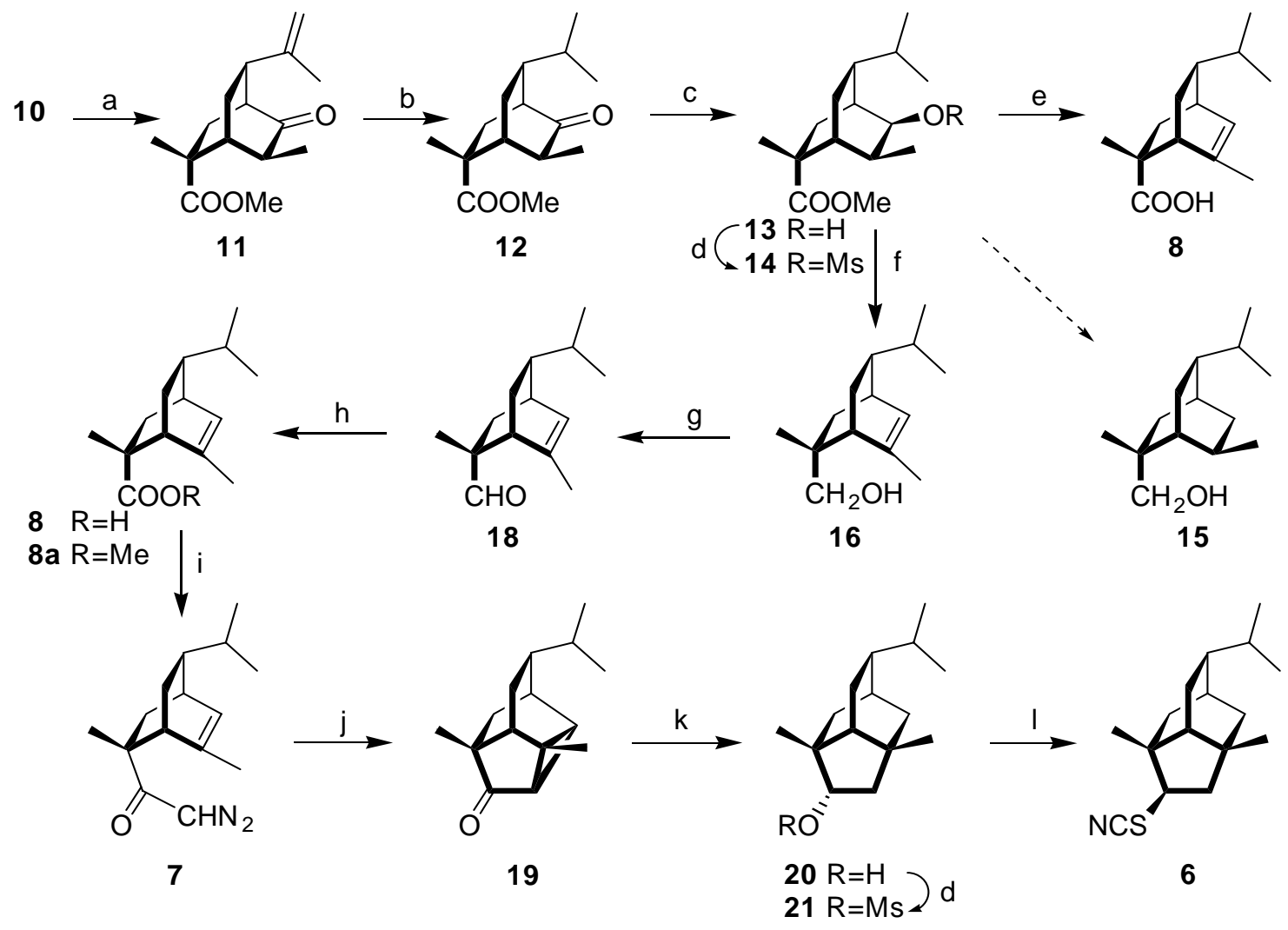

Scheme 2. Reagents: (a) LiHMDS, $\mathrm{CH}_{2}=\mathrm{C}\left(\mathrm{Me}\right.$ )COOMe; (b) $\mathrm{H}_{2}, 10 \% \mathrm{Pt} / \mathrm{C}$; (c) $\mathrm{NaBH}_{4}$; (d) $\mathrm{MsCl}$, py, DMAP; (e) NaOEt; (f) LAH; (g) PCC, NaOAc; (h) Jones' reagent; (i) $(\mathrm{COCl})_{2} ; \mathrm{CH}_{2} \mathrm{~N}_{2}$; (j) $\mathrm{CuSO}_{4}$; (k) Li, liq. $\mathrm{NH}_{3}$; (l) KSCN. 
In the ${ }^{1} \mathrm{H}$ NMR spectrum, presence of a doublet at $\delta 5.64(\mathrm{~J} 6.0 \mathrm{~Hz})$ due to the olefinic proton, a typical AB quartet at 3.19 and 3.09 due to the hydroxymethyl protons, two singlets at 1.78 and 1.07 due to the olefinic and tertiary methyl groups, respectively, established the structure of the alcohol 16, which was confirmed by the ${ }^{13} \mathrm{C}$ NMR spectrum.

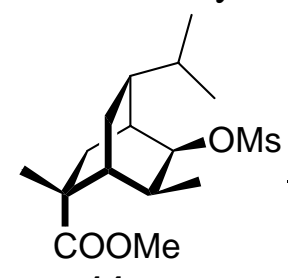

14

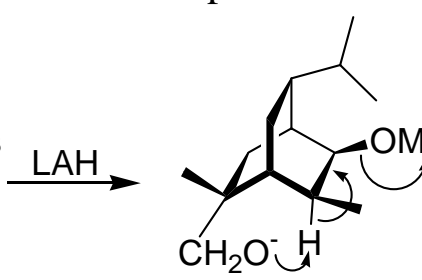

$17 \mathrm{a}$

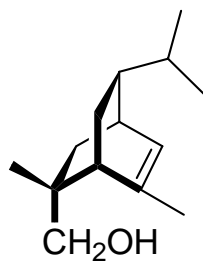

16

\section{Scheme 3}

Formation of the alcohol $\mathbf{1 6}$ can be explained as shown in Scheme 3. First reduction of the ester group generates the alkoxide 17a, which acts as an intramolecular base and brings out the $\mathrm{E}_{2}$-elimination of the mesylate. This was further established by carrying out the reaction in two distinct steps. Thus, reduction of the ester group in the mesylate $\mathbf{1 4}$ with LAH at low temperature furnished the hydroxy mesylate $\mathbf{1 7}$ in $82 \%$ yield. Treatment of the alcohol $\mathbf{1 7}$ with one equivalent of $n$-butyllithium in THF furnished the alcohol 16. It is worth noting that the steric crowding plays an important role in this elimination reaction. For example, elimination of the mesylate was found to be a minor pathway when the isopropyl group in $\mathbf{1 4}$ was replaced by the isopropenyl group.

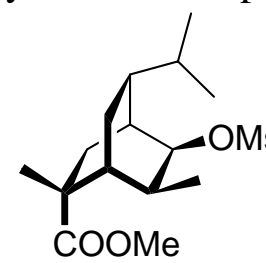

14

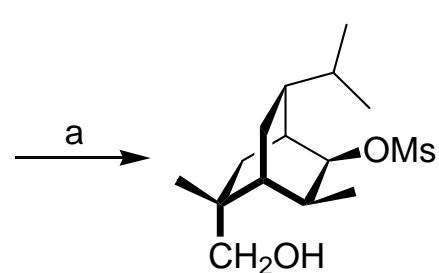

17

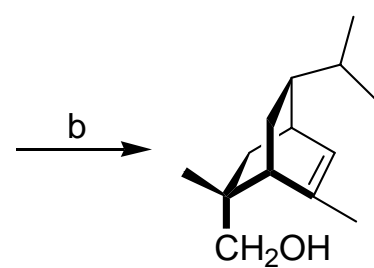

16

(a) $\mathrm{LiAlH}_{4},-70{ }^{\circ} \mathrm{C}$; (b) $n$-BuLi, rt

Since the olefinic alcohol $\mathbf{1 6}$ was readily available, it was transformed into the acid $\mathbf{8}$. Thus, oxidation of the alcohol $\mathbf{1 6}$ with PCC and sodium acetate in dichloromethane furnished the aldehyde 18 in $80 \%$ yield, which on further oxidation with $1.6 \mathrm{M}$ Jones' reagent in acetone furnished the acid $\mathbf{8}$ in 98\% yield, which was characterized as its methyl ester $\mathbf{8 a}$. The acid $\mathbf{8}$ was then transformed into the tetracyclic ketone 19 via intramolecular cyclopropanation reaction ${ }^{11}$ of the diazo ketone 7. Thus, reaction of the acid $\mathbf{8}$ with oxalyl chloride furnished the acid chloride, which upon treatment with an excess of ethereal diazomethane furnished the diazo ketone 7 in $88 \%$ yield. Anhydrous copper sulfate catalyzed decomposition of the diazo ketone $\mathbf{7}$ in refluxing cyclohexane led to the formation of the tetracyclic ketone 19, m.p. $61-63^{\circ} \mathrm{C}$, via stereospecific insertion of the intermediate keto carbenoid, in $60 \%$ yield, whose structure was established from its spectral data. It was anticipated that regioselective cyclopropane ring cleavage of the tetracyclic ketone 19 would generate neopupukean-4-one $\mathbf{9}$, since it is well established ${ }^{12}$ that in the reaction of cyclopropyl 
ketones using lithium in liquid ammonia reduction conditions, the cyclopropane bond which has better overlap with the carbonyl $\pi$-orbital will be cleaved. Thus, reaction with an excess of lithium in liquid ammonia transformed the tetracyclic ketone 19 directly into the endo neopupukean-4-ol 20, m.p. $57-59{ }^{\circ} \mathrm{C}$, instead of the ketone $\mathbf{9}$, in a regio and stereoselective manner. Oxidation of the alcohol 20 with PCC and silica gel in methylene chloride furnished neopupukean-4-one 9, which exhibited spectral data (IR, ${ }^{1} \mathrm{H}$ and ${ }^{13} \mathrm{C}$ NMR) identical to that of the sample ${ }^{7 \mathrm{e}}$ obtained earlier. Stereoselective reduction of the ketone group in $\mathbf{9}$ with sodium borohydride in methanol at ice temperature furnished the alcohol 20, establishing unambiguously the endo stereochemistry of the hydroxy group in the alcohol 20. Reaction of the alcohol $\mathbf{2 0}$ with methanesulfonyl chloride in pyridine in the presence of a catalytic amount of DMAP furnished the methanesulfonate 21, m.p. $52-54{ }^{\circ} \mathrm{C}$, in $84 \%$ yield, which on reaction with potassium thiocyanate in acetone in a sealed tube furnished 4-thiocyanatoneopupukeanane 6 in $68 \%$ yield $[\alpha]_{D}^{28}:-117.6$ (c 1.08, $\mathrm{CHCl}_{3}$ ), which exhibited optical rotation and spectral data identical to those of the natural product. $^{3}$
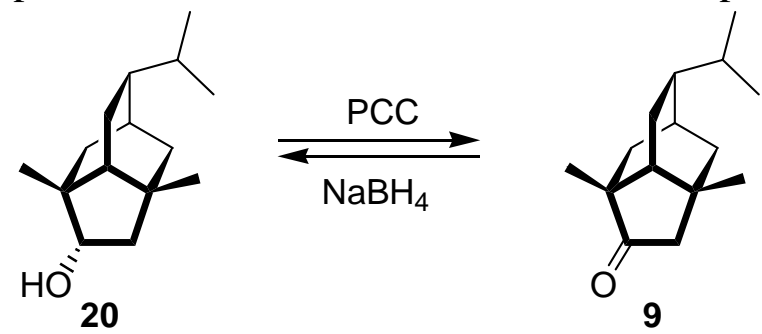

In conclusion, we have developed an enantiospecific approach to the natural enantiomer of the marine sesquiterpene, 4-thiocyanatoneopupukeanane starting from the readily available monoterpene $(R)$-carvone, employing Michael-Michael addition, intramolecular alkoxide mediated $\mathrm{E}_{2}$-elimination of a mesylate, intramolecular diazo ketone cyclopropanation and regiospecific cyclopropane ring cleavage as key reactions.

\section{Experimental Section}

General Procedures. Melting points are recorded using Tempo and Mettler FP1 melting point apparatus and are uncorrected. IR spectra were recorded on Perkin Elmer 781 and Jasco FTIR 410 spectrophotometers. ${ }^{1} \mathrm{H}$ (300 MHz) and ${ }^{13} \mathrm{C}$ (75 and $22.5 \mathrm{MHz}$ ) NMR spectra were recorded on Jeol JNM $\lambda$-300 and FX-90Q spectrometers. The chemical shifts ( ppm) and coupling constants (Hz) are reported in standard fashion with reference to either internal tetramethylsilane (for ${ }^{1} \mathrm{H}$ ) or the central line (77.1 ppm) of $\mathrm{CDCl}_{3}$ (for ${ }^{13} \mathrm{C}$ ). In the ${ }^{13} \mathrm{C}$ NMR spectra, the nature of the carbons (C, $\mathrm{CH}, \mathrm{CH}_{2}$ or $\mathrm{CH}_{3}$ ) was determined by the DEPT-135 experiment, and are given in parentheses. Mass spectra were recorded using Jeol JMS-DX 303 GCMS instrument and relative intensities are given in parentheses. Elemental analyses were carried out using Carlo Erba 1106 CHN analyser. Optical rotations were measured using a Jasco DIP-370 digital polarimeter and $[\alpha]_{\mathrm{D}}$ values are given in units of $10^{-1} \mathrm{deg} \mathrm{cm}^{2} \mathrm{~g}^{-1}$. Acme's silica gel (100-200 mesh) was used for column chromatography. All small-scale dry reactions were carried out using standard syringe septum technique. Low 
temperature reactions were conducted in a bath made of alcohol and liquid nitrogen. Dry THF was obtained by distillation over sodium-benzophenone ketyl. Dry ether and hexane were obtained by distillation over sodium and stored over sodium wire. Dry dichloromethane was prepared by distilling over calcium hydride. Copper sulfate was dried by irradiation in a microwave oven prior to use. Liquid ammonia was obtained in cylinders from Mysore Ammonia Ltd. and distilled over sodium prior to use.

(-)-Methyl $\quad(1 R, 2 R, 4 S, 5 S, 6 S, 8 S)-5$-hydroxy-8-isopropyl-2,6-dimethylbicyclo[2.2.2]octane-2carboxylate (13). To a cold $\left(0^{\circ} \mathrm{C}\right)$ magnetically stirred solution of the keto ester ${ }^{7 \mathrm{e}} \mathbf{1 2}(1.0 \mathrm{~g}$, $3.94 \mathrm{mmol}$ ) in $5 \mathrm{ml}$ of $\mathrm{MeOH}$ was added $\mathrm{NaBH}_{4}(200 \mathrm{mg}, 5.28 \mathrm{mmol}$ ) over a period of $5 \mathrm{~min}$. The reaction mixture was stirred for $15 \mathrm{~min}$ at the same temperature and then the solvent was evaporated under reduced pressure. It was then diluted with water $(5 \mathrm{ml})$ and extracted with ether $(3 \mathrm{x} 10 \mathrm{ml})$. The ether extract was washed with brine and dried $\left(\mathrm{Na}_{2} \mathrm{SO}_{4}\right)$. Evaporation of the solvent and purification of the product over a silica gel column using ethyl acetate-hexane as eluent furnished the alcohol 13 (857 mg, 85\%), which was recrystallized from hexane. m.p.: $68-70{ }^{\circ} \mathrm{C} .[\alpha]_{D}^{26}:-79.1$ (c 1.82, $\mathrm{CHCl}_{3}$ ). IR (neat): $v_{\max } / \mathrm{cm}^{-1} 3530,1725 .{ }^{1} \mathrm{H}$ NMR $\quad$ (300 MHz, $\left.\mathrm{CDCl}_{3}\right): \delta 3.95(1 \mathrm{H}, \mathrm{dd}, J$ 11.6 and $3.5 \mathrm{~Hz}, \mathrm{CHOH}), 3.67$ (3 H, s, $\mathrm{COOCH}_{3}$ ), 2.33 (1 H, dd, J 14.1 and $2.4 \mathrm{~Hz}$ ), 2.09 (1 H, br s), 2.00-1.50 (5 H, m), 1.43 (1 H, dd, $J 14.1$ and $8.7 \mathrm{~Hz}), 1.30$ (3 H, s, tert-CH $\left.\mathrm{CH}_{3}\right), 21$ (1 H, dd, $J$ 14.1 and $4.2 \mathrm{~Hz}$ ), 1.05-0.90 (1 H, m), 1.01 (3 H, d, $\left.J 6.9 \mathrm{~Hz}, s e c-\mathrm{CH}_{3}\right), 0.92$ (3 H, d, $J 6.0 \mathrm{~Hz}$ ) and $0.86(3 \mathrm{H}, \mathrm{d}, J 6.3 \mathrm{~Hz})\left[\mathrm{CH}\left(\mathrm{CH}_{3}\right)_{2}\right] .{ }^{13} \mathrm{C} \mathrm{NMR}\left(22.5 \mathrm{MHz}, \mathrm{CDCl}_{3}\right): \delta 179.5(\mathrm{~s}, \mathrm{O}-\mathrm{C}=\mathrm{O}), 71.1$ (d, $\mathrm{CHOH}$ ), 51.8 (q, $\mathrm{COOCH}_{3}$ ), 45.2 (s, C-2), 42.2 (d), 39.9 (d), 36.1 (t, C-3), 34.4 (d), 33.6 (2 C, d), 26.2 (q), 22.6 (q), 21.8 (t, C-7), 21.1 (q), 12.5 (q, sec-CH - $_{3}$. Mass: m/z 254 (M+27\%), 236 (18), 136 (57), 121 (20), 109 (73), 107 (90), 93 (100), 92 (50). Anal.: For $\mathrm{C}_{15} \mathrm{H}_{26} \mathrm{O}_{3}$, Calcd.: C, 70.83; H, 10.30. Found: C, 71.20; H, 10.68\%.

(-)-Methyl (1R,2R,4S,5S,6S,8S)-8-isopropyl-5-methanesulfonyloxy-2,6-dimethylbicyclo[2.2.2]octane-2-carboxylate (14). To a magnetically stirred solution of the alcohol 13 (500 mg, $1.97 \mathrm{mmol})$ in pyridine $(3 \mathrm{ml})$ was added a catalytic amount of DMAP followed by methanesulfonyl chloride $(0.16 \mathrm{ml}, 2.07 \mathrm{mmol})$ and the reaction mixture was stirred for $72 \mathrm{~h}$ at RT. It was then diluted with $5 \mathrm{ml}$ of water and extracted with $\mathrm{CH}_{2} \mathrm{Cl}_{2}(3 \times 10 \mathrm{ml})$. The organic layer was washed with $3 \mathrm{~N}$ aq. $\mathrm{HCl}$, saturated aq. $\mathrm{NaHCO}_{3}$ solution and brine, and dried $\left(\mathrm{Na}_{2} \mathrm{SO}_{4}\right)$. Evaporation of the solvent and purification of the residue on a silica gel column using ethyl acetatehexane (1:10 to 1:5) as eluent furnished the mesylate 14 (390 mg, 60\%), which was recrystallized from a mixture of hexane and ether. m.p.: 67-69 ${ }^{\circ} \mathrm{C}$. $[\alpha]_{D}^{22}$ : -45.7 (c 1.40, $\mathrm{CHCl}_{3}$ ). IR (neat): $v_{\max } / \mathrm{cm}^{-1} 1720,1350,1280,1210,1170 .{ }^{1} \mathrm{H}$ NMR (300 MHz, $\left.\mathrm{CDCl}_{3}\right): \delta 4.84(1 \mathrm{H}, \mathrm{dd}, J 10.5$ and $4.0 \mathrm{~Hz}, \mathrm{CHOMs}$ ), 3.68 (3 H, s, $\left.\mathrm{COOCH}_{3}\right), 2.96$ (3 H, s, $\left.\mathrm{OSO}_{2} \mathrm{CH}_{3}\right), 2.40$ (1 H, dd, J 14.4 and 2.2 Hz), 2.31 (1 H, br s), 2.05-1.80 (2 H, m), 1.80-1.65 (2 H, m), 1.61 (1 H, br s), 1.50-1.35 (1 H, m), 1.31 (3 H, s, tert- $\left.\mathrm{CH}_{3}\right), 1.10-1.00(1 \mathrm{H}, \mathrm{m}), 1.06$ (3 H, d, $\left.J 7.2 \mathrm{~Hz}, \mathrm{sec}-\mathrm{CH}_{3}\right), 0.93$ (3 H, d, J 6.6 Hz) and $0.88(3 \mathrm{H}, \mathrm{d}, J 6.3 \mathrm{~Hz})\left[\mathrm{CH}\left(\mathrm{CH}_{3}\right)_{2}\right] .{ }^{13} \mathrm{C} \mathrm{NMR}\left(75 \mathrm{MHz}, \mathrm{CDCl}_{3}\right): \delta 178.6(\mathrm{O}-\mathrm{C}=\mathrm{O}), 81.7$ (CHOMs), $52.2\left(\mathrm{COOCH}_{3}\right), 44.9$ (quat-C), 41.6, 39.5, 37.7, 35.5, 33.5, 33.1, 32.9, 26.1, 22.4, 21.7, 
20.9, 13.5 (sec- $-\mathrm{CH}_{3}$ ). Mass: m/z 253 (M-SO $\left.\mathrm{CH}_{3}, 2 \%\right), 237$ (62), 177 (25), 136 (100), 107 (47), 93 (95), 92 (65). Anal.: For $\mathrm{C}_{16} \mathrm{H}_{28} \mathrm{O}_{5} \mathrm{~S}$, Calcd.: C, 57.81; H, 8.49. Found: C, 58.04; H, 8.76\%.

(+)-(1R,2R,4S,8S)-8-Isopropyl-2,6-dimethylbicyclo[2.2.2]oct-5-ene-2-methanol (16). To a magnetically stirred solution of the mesylate 14 (150 mg, $0.45 \mathrm{mmol})$ in THF (2 ml) was added LAH (50 mg, $1.32 \mathrm{mmol}$ ) in one portion and the resulting mixture was refluxed for $8 \mathrm{~h}$. It was then cooled, diluted with ether $(5 \mathrm{ml})$ and excess $\mathrm{LAH}$ was quenched carefully with a few drops of water. The ethereal layer was separated and aqueous phase was extracted with ether (2 x $10 \mathrm{ml})$. The combined organic extract was washed with brine and dried $\left(\mathrm{Na}_{2} \mathrm{SO}_{4}\right)$. Evaporation of the solvent and purification of the residue on a silica gel column using ethyl acetate-hexane (1:10) as eluent furnished the alcohol 16 (75 mg, 80\%) as oil. $[\alpha]_{D}^{26}: 30.6$ (c 1.08, $\mathrm{CHCl}_{3}$ ). IR (neat): $v_{\max } / \mathrm{cm}^{-1}$ 3360. ${ }^{1} \mathrm{H}$ NMR (300 MHz, $\mathrm{CDCl}_{3}$ ): $\delta 5.64$ (1 H, d, $J 6.0 \mathrm{~Hz}$, olefinic H), 3.19 (1 H, d, $J$ $10.2 \mathrm{~Hz}$ ) and 3.09 (1 H, d, $J 10.2 \mathrm{~Hz}$ ) [CH $2 \mathrm{OH}$ ], 2.49 (1 H, m), 2.05 (1 H, br s), 1.97 (1 H, ddd, $J$ 12.6, 9.0 and $3.1 \mathrm{~Hz}), 1.78$ (3 H, s, olefinic $\left.\mathrm{CH}_{3}\right), 1.51$ (1 H, br s, OH), 1.23 (1 H, q, J 8.1 Hz), 1.15$0.70(4 \mathrm{H}, \mathrm{m}), 1.07\left(3 \mathrm{H}, \mathrm{s}\right.$, tert- $\left.\mathrm{CH}_{3}\right), 0.85(3 \mathrm{H}, \mathrm{d}, J 6.6 \mathrm{~Hz})$ and $0.78(3 \mathrm{H}, \mathrm{d}, J 6.6 \mathrm{~Hz})$ $\left[\mathrm{CH}\left(\mathrm{CH}_{3}\right)_{2}\right] .{ }^{13} \mathrm{C} \mathrm{NMR}\left(75 \mathrm{MHz}_{,} \mathrm{CDCl}_{3}\right): \delta 143.0(\mathrm{C}=\mathrm{CH}), 123.0(\mathrm{C}=\mathrm{CH}), 72.2\left(\mathrm{CH}_{2} \mathrm{OH}\right), 45.6$, 42.9, 39.4, 37.9 (C-2), 34.0, 33.7, 28.6, 24.1, 21.2, 21.1, 20.4. Mass: 208 ( $\left.\mathrm{M}^{+}, \mathrm{C}_{14} \mathrm{H}_{24} \mathrm{O}, 16 \%\right), 136$ (22), 107 (100), 93 (70), 92 (42), 91 (76).

(+)-(1S,2R,4S,8S)-8-Isopropyl-2,6-dimethylbicyclo[2.2.2]oct-5-ene-2-carboxylic acid (8). To a magnetically stirred solution of the alcohol 16 (75 mg, $0.36 \mathrm{mmol})$ in $\mathrm{CH}_{2} \mathrm{Cl}_{2}(1 \mathrm{ml})$ was added a homogeneous mixture of PCC (155 mg, $0.72 \mathrm{mmol}$ ) and NaOAc (155 mg) and the reaction mixture was stirred at RT for $4 \mathrm{~h}$. It was then filtered through a short pad of silica gel and washed with an excess of $\mathrm{CH}_{2} \mathrm{Cl}_{2}$. Evaporation of the solvent and purification of the residue on a silica gel column using ethyl acetate-hexane (1:20 to $1: 10$ ) as eluent furnished the aldehyde 18 (59 mg, 80\%). $[\alpha]_{D}^{27}$ : 26.3 (с 1, $\mathrm{CHCl}_{3}$ ). IR (neat): $v_{\max } / \mathrm{cm}^{-1}$ 2700, 1720. ${ }^{1} \mathrm{H}$ NMR (300 MHz, $\left.\mathrm{CDCl}_{3}\right): \delta 9.32$ (1 H, s, CHO), 5.73 (1 H, d, J 6.0 Hz, olefinic H), 2.60 (1 H, br s), 2.23 (1 H, br s), 2.02 (1 H, ddd, J 12.6, 8.7 and $3.9 \mathrm{~Hz}), 1.95$ (1 H, dd, $J 13.2$ and $3.9 \mathrm{~Hz}), 1.74$ (3 H, s, olefinic $\left.\mathrm{CH}_{3}\right), 1.50-0.85$ (4 H, m), $1.12\left(3 \mathrm{H}, \mathrm{s}\right.$, tert- $\left.\mathrm{CH}_{3}\right), 0.86(3 \mathrm{H}, \mathrm{d}, J 6.6 \mathrm{~Hz})$ and $0.79(3 \mathrm{H}, \mathrm{d}, J 6.3 \mathrm{~Hz})\left[\mathrm{CH}\left(\mathrm{CH}_{3}\right)_{2}\right] .{ }^{13} \mathrm{C} \mathrm{NMR}$ (75 MHz, $\left.\mathrm{CDCl}_{3}\right): \delta 205.9(\mathrm{C}=\mathrm{O}), 141.8(\mathrm{C}=\mathrm{CH}), 125.0(\mathrm{C}=\mathrm{CH}), 49.1(\mathrm{C}-2), 46.2,42.5,36.8$, 33.57, 33.55, 27.7, 21.11, 21.10, 20.7, 20.4. Mass: m/z $206\left(\mathrm{M}^{+}, \mathrm{C}_{14} \mathrm{H}_{22} \mathrm{O}, 5 \%\right), 136$ (10), 107 (100), 93 (26), 91 (40). To a cold $\left(0^{\circ} \mathrm{C}\right)$ magnetically stirred solution of the aldehyde 18 (50 mg, $0.24 \mathrm{mmol})$ in acetone $(1 \mathrm{ml})$ was added Jones' reagent $(0.8 \mathrm{ml}, 1.6 \mathrm{M}$ solution, $1.28 \mathrm{mmol})$ and stirred for $1 \mathrm{~h}$. Isopropyl alcohol $(2 \mathrm{ml}$ ) was added to consume the excess Jones' reagent. The solvent was then removed under reduced pressure; the residue was taken in $5 \mathrm{ml}$ of water and extracted with $\mathrm{CH}_{2} \mathrm{Cl}_{2}(3 \times 5 \mathrm{ml})$. The organic phase was washed with brine and dried $\left(\mathrm{Na}_{2} \mathrm{SO}_{4}\right)$. Evaporation of the solvent gave the acid 8 (53 mg, 98\%). IR (neat): $v_{\max } / \mathrm{cm}^{-1} 3100,1690 .{ }^{1} \mathrm{H} \mathrm{NMR}$ (90 MHz, $\mathrm{CDCl}_{3}$ ): $\delta 7.40$ (1 H, br s, $\left.\mathrm{COOH}\right), 5.70$ (1 H, d, J $\left.6.4 \mathrm{~Hz}, \mathrm{C}=\mathrm{CH}\right), 2.70-2.40$ (2 H, m), 2.20 (1 H, dd, $J 13.0$ and $3.5 \mathrm{~Hz}$ ), 2.10-1.00 (5 H, m), 1.77 (3 H, d, $J 1.5 \mathrm{~Hz}$, olefinic $\mathrm{CH}_{3}$ ), 1.35 (3 $\mathrm{H}, \mathrm{s}$, tert $\left.-\mathrm{CH}_{3}\right), 0.87(3 \mathrm{H}, \mathrm{d}, J 6.3 \mathrm{~Hz})$ and $0.83(3 \mathrm{H}, \mathrm{d}, J 6.3 \mathrm{~Hz})\left[\mathrm{CH}\left(\mathrm{CH}_{3}\right)_{2}\right]$. Mass: $222\left(\mathrm{M}^{+}\right.$, $\mathrm{C}_{14} \mathrm{H}_{22} \mathrm{O}_{2}$, 5\%), 152 (20), 136 (11), 107 (100), 93 (34). Esterification of a small sample of the acid 8 with ethereal diazomethane gave the ester 8a. $[\alpha]_{D}^{26}: 6.1$ (c 1.32, $\mathrm{CHCl}_{3}$ ). IR (neat): $v_{\max } / \mathrm{cm}^{-1} 1730$. 
${ }^{1} \mathrm{H}$ NMR (300 MHz, $\left.\mathrm{CDCl}_{3}\right): \delta 5.68(1 \mathrm{H}, \mathrm{d}, J 6.0 \mathrm{~Hz}, \mathrm{C}=\mathrm{CH}), 3.62\left(3 \mathrm{H}, \mathrm{s}, \mathrm{COOCH}_{3}\right), 2.49(2 \mathrm{H}$, m), 2.23 (1 H, dd, $J 13.2$ and $4.0 \mathrm{~Hz}$ ), 1.97 (1 H, ddd, $J$ 12.6, 9.9 and $2.7 \mathrm{~Hz}$ ), 1.72 (3 H, s, olefinic $\left.\mathrm{CH}_{3}\right), 1.30-0.85(4 \mathrm{H}, \mathrm{m}), 1.27\left(3 \mathrm{H}, \mathrm{s}\right.$, tert- $\left.\mathrm{CH}_{3}\right), 0.84(3 \mathrm{H}, \mathrm{d}, J 6.3 \mathrm{~Hz})$ and $0.78(3 \mathrm{H}, \mathrm{d}, J 6.6 \mathrm{~Hz})$ $\left[\mathrm{CH}\left(\mathrm{CH}_{3}\right)_{2}\right] .{ }^{13} \mathrm{C} \mathrm{NMR}\left(75 \mathrm{MHz}, \mathrm{CDCl}_{3}\right): \delta 178.8(\mathrm{O}-\mathrm{C}=\mathrm{O}), 142.7(\mathrm{C}=\mathrm{CH}), 124.4(\mathrm{C}=\mathrm{CH}), 51.6$ $\left(\mathrm{COOCH}_{3}\right)$, 45.9, 45.3 (C-2), 43.6, 39.6, 33.7, 33.6, 27.2, 25.7, 21.1, 20.4, 20.2. Mass: m/z $236\left(\mathrm{M}^{+}\right.$, $\left.\mathrm{C}_{15} \mathrm{H}_{24} \mathrm{O}_{2}, 9 \%\right), 166$ (12), 136 (11), 107 (100), 93 (30), 91 (42).

(-)-(1R,2S,3R,4S,6R,8S,9S)-9-Isopropyl-2,6,dimethyltetracyclo[4.4.0.0 $\left.{ }^{2,4} 0^{3,8}\right]$ decan-5-one (19). To a magnetically stirred solution of the acid 8 (160 mg, $0.72 \mathrm{mmol})$ in dry benzene (1 ml) was added oxalyl chloride $(0.31 \mathrm{ml}, 3.6 \mathrm{mmol})$ and the reaction mixture was stirred for $2 \mathrm{~h}$ at $\mathrm{RT}$. Evaporation of benzene and the excess oxalyl chloride under reduced pressure furnished the acid chloride, which was taken in dry ether $(2 \mathrm{ml})$ and added, dropwise, to a cold $\left(0{ }^{\circ} \mathrm{C}\right)$ magnetically stirred solution of diazomethane $(10 \mathrm{ml}$, prepared from $1.0 \mathrm{~g}$ of $N$-nitroso- $N$-methylurea and $15 \mathrm{ml}$ of $60 \%$ aq. $\mathrm{KOH}$ solution). The reaction mixture was slowly warmed up to RT, stirred for $2 \mathrm{~h}$ and the excess diazomethane and ether were carefully evaporated on a water bath. Rapid purification by filtration of the crude product through neutral alumina using $\mathrm{CH}_{2} \mathrm{Cl}_{2}$ as eluent furnished the diazo ketone 7 (156 mg, 88\%) as yellow oil. IR (neat): $v_{\max } / \mathrm{cm}^{-1} 2100,1630$. To a magnetically stirred, refluxing (by keeping two $100 \mathrm{~W}$ tungsten lamps near the flask) suspension of anhydrous copper sulfate $(680 \mathrm{mg}$ ) in $20 \mathrm{ml}$ of dry cyclohexane was added, dropwise, a solution of the diazo ketone 7 (156 mg, $0.63 \mathrm{mmol}$ ) in cyclohexane $(5 \mathrm{ml}$ ) over a period of $15 \mathrm{~min}$ and the reaction mixture was refluxed for $4 \mathrm{~h}$. It was then cooled and copper sulfate was filtered off using a sintered funnel. Evaporation of the solvent and purification of the residue on a silica gel column using ethyl acetatehexane (1:20 to 1:10) as eluent furnished the tetracyclic ketone 19 (83 $\mathrm{mg}, 60 \%)$, which was recrystallized from a mixture of hexane and ether. m.p.: $61-63{ }^{\circ} \mathrm{C}$. $[\alpha]_{D}^{26}:-17.9$ (c $1.40, \mathrm{CHCl}_{3}$ ). IR (neat): $v_{\max } / \mathrm{cm}^{-1} 1720 .{ }^{1} \mathrm{H}$ NMR (300 MHz, $\left.\mathrm{CDCl}_{3}\right): \delta 2.25-2.15(1 \mathrm{H}, \mathrm{m}), 1.80-1.65(4 \mathrm{H}, \mathrm{m}), 1.60-$ 1.40 (3 H, m), 1.30 (3 H, s, tert-CH $\mathrm{CH}_{3}, 1.25-1.05$ (2 H, m), 0.96 (3 H, d, $J 6.6 \mathrm{~Hz}$ ) and 0.94 (3 H, d, $J$ $6.9 \mathrm{~Hz})\left[\mathrm{CH}\left(\mathrm{CH}_{3}\right)_{2}\right], 0.91\left(3 \mathrm{H}, \mathrm{s}\right.$, tert- $\left.\mathrm{CH}_{3}\right) .{ }^{13} \mathrm{C} \mathrm{NMR}\left(75 \mathrm{MHz}, \mathrm{CDCl}_{3}\right): \delta 214.4(\mathrm{C}, \mathrm{C}=\mathrm{O}), 46.8$ (CH), 45.6 (C, C-6), $43.8\left(\mathrm{CH}_{2}, \mathrm{C}-7\right), 41.3(\mathrm{CH}), 33.7(\mathrm{CH}), 33.2(\mathrm{CH}), 31.7(\mathrm{CH}), 31.6(\mathrm{C}, \mathrm{C}-2)$, $25.7(\mathrm{CH}), 21.3\left(\mathrm{CH}_{3}\right)$ and $21.2\left(\mathrm{CH}_{3}\right)\left[\mathrm{CH}_{3}-\mathrm{CH}-\mathrm{CH}_{3}\right], 21.1\left(\mathrm{CH}_{2}, \mathrm{C}-10\right), 17.8\left(\mathrm{CH}_{3}\right), 15.9\left(\mathrm{CH}_{3}\right)$. Mass: m/z 218 (M+, 52\%), 190 (M-CO, 43), 175 (35), 147 (62), 135 (26), 119 (39), 107 (100), 105 (70), 95 (40), 93 (45), 91 (50). Anal.: For $\mathrm{C}_{15} \mathrm{H}_{22} \mathrm{O}$, Calcd.: C, 82.52; H, 10.16. Found: C, 81.93; H, $10.62 \%$.

(-)-(1S,3R,4S,6R,7R,9S)-9-Isopropyl-3,6-dimethyltricyclo[4.3.1.0 $\left.{ }^{3,7}\right]$ decan-4-ol $\quad(20) . \quad$ To a magnetically stirred solution of lithium $(10 \mathrm{mg}, 1.43 \mathrm{mmol}$ ) in $30 \mathrm{ml}$ of freshly distilled (over sodium) ammonia was added, dropwise, a solution of the tetracyclic ketone 19 (65 mg, $0.3 \mathrm{mmol}$ ) in THF ( $1 \mathrm{ml})$. The reaction mixture was stirred for $30 \mathrm{~min}$ and then quenched with ammonium chloride. Ammonia was evaporated; the reaction mixture was diluted with $5 \mathrm{ml}$ of water and extracted with ether $(3 \times 5 \mathrm{ml})$. The ether extract was washed with brine and dried $\left(\mathrm{Na}_{2} \mathrm{SO}_{4}\right)$. Evaporation of the solvent and purification of the residue on a silica gel column using ethyl acetatehexane (1:10) as eluent furnished neopupukean-4-ol 20 (55 mg, 83\%), which was recrystallized from a mixture of hexane and ether. ${ }^{7 \mathrm{e}}$ m.p.: $57-59{ }^{\circ} \mathrm{C}$. $[\alpha]_{D}^{26}:-66.1$ (c 1.12, $\mathrm{CHCl}_{3}$ ). IR (neat): 
$v_{\max } / \mathrm{cm}^{-1}$ 3360. ${ }^{1} \mathrm{H}$ NMR (300 MHz, $\left.\mathrm{CDCl}_{3}\right): \delta 3.62$ (1 H, dd, J 9.9 and $\left.6.6 \mathrm{~Hz}, \mathrm{H}-4\right), 2.03$ (1 H, dd, $J 13.8$ and $9.9 \mathrm{~Hz}$ ), 1.91 (1 H, dd, $J 13.8$ and $3.5 \mathrm{~Hz}$ ), $1.74(1 \mathrm{H}$, ddd, $J$ 14.4, 9.9 and $4.5 \mathrm{~Hz}), 1.66$ (1 H, br s), 1.58 (1 H, br s, OH), 1.40 (1 H, d, J 15.0 Hz), 1.35-0.80 (7 H, m), 1.01 (3 H, s) and 0.96 $(3 \mathrm{H}, \mathrm{s})$ [2 x tert- $\left.\mathrm{CH}_{3}\right], 0.89(3 \mathrm{H}, \mathrm{d}, J 6.6 \mathrm{~Hz})$ and $0.83(3 \mathrm{H}, \mathrm{d}, J 6.6 \mathrm{~Hz})\left[\mathrm{CH}\left(\mathrm{CH}_{3}\right)_{2}\right] .{ }^{13} \mathrm{C} \mathrm{NMR}$ (75 MHz, $\left.\mathrm{CDCl}_{3}\right): \delta 78.8(\mathrm{CH}, \mathrm{CHOH}), 50.4\left(\mathrm{CH}_{2}\right), 46.7(\mathrm{CH}), 44.6(\mathrm{CH}), 42.9(\mathrm{C}, \mathrm{C}-3), 39.6$ $\left(\mathrm{CH}_{2}\right), 38.2$ (C, C-6), $34.7\left(\mathrm{CH}_{2}\right), 31.9(\mathrm{CH}), 27.5(\mathrm{CH}), 26.8\left(\mathrm{CH}_{3}\right), 24.5\left(\mathrm{CH}_{3}\right), 23.0\left(\mathrm{CH}_{2}, \mathrm{C}-8\right)$, $21.2\left(\mathrm{CH}_{3}\right), 21.0\left(\mathrm{CH}_{3}\right)$. Mass: m/z $222\left(\mathrm{M}^{+}, \mathrm{C}_{15} \mathrm{H}_{26} \mathrm{O}, 1 \%\right), 205(\mathrm{M}-\mathrm{OH}, 20), 204\left(\mathrm{M}-\mathrm{H}_{2} \mathrm{O}, 22\right), 161$ (35), 136 (44), 119 (32), 107 (100), 105 (50), 93 (56).

\section{(-)-(1S,3R,4S,6R,7R,9S)-9-Isopropyl-3,6-dimethyltricyclo[4.3.1.0 $\left.{ }^{3,7}\right]$ dec-4-yl methanesulfonate}

(21). To a magnetically stirred solution of the alcohol 20 (44 mg, $0.19 \mathrm{mmol}$ ) in $1 \mathrm{ml}$ of pyridine were added methanesulfonyl chloride $(0.02 \mathrm{ml}, 0.26 \mathrm{mmol})$ and a catalytic amount of DMAP. The reaction mixture was stirred for $10 \mathrm{~h}$ at RT. It was then diluted with $5 \mathrm{ml}$ of water and extracted with $\mathrm{CH}_{2} \mathrm{Cl}_{2}$ (3 x $5 \mathrm{ml}$ ). The organic extract was washed successively with $3 \mathrm{~N}$ aq. $\mathrm{HCl}$, saturated aq. $\mathrm{NaHCO}_{3}$ solution and brine, and dried $\left(\mathrm{Na}_{2} \mathrm{SO}_{4}\right)$. Evaporation of the solvent and purification of the product on a silica gel column using ethyl acetate-hexane (1:10) as eluent furnished the mesylate 21 (50 mg, 84\%), which was recrystallized from a mixture of hexane and ether. m.p.: 52-54 ${ }^{\circ} \mathrm{C}$. $[\alpha]_{D}^{22}:-21.0$ (c 1.49, $\mathrm{CHCl}_{3}$ ). IR (neat): $v_{\max } / \mathrm{cm}^{-1} 1350,1170 .{ }^{1} \mathrm{H} \mathrm{NMR}$ (300 $\mathrm{MHz}, \mathrm{CDCl}_{3}$ ): $\delta 4.44$ (1 H, dd, J 9.9 and $6.3 \mathrm{~Hz}, \mathrm{H}-4), 3.00$ (3 H, s, OSO $\mathrm{CH}_{3}$ ), 2.17 (1 H, dd, $J 14.4$ and $9.9 \mathrm{~Hz}$ ), 1.95 (1 H, dd, $J 13.8$ and $3.6 \mathrm{~Hz}$ ), 1.77 (1 H, ddd, $J$ 14.4, 9.9 and $4.5 \mathrm{~Hz}$ ), 1.68 (1 H, br s), 1.61 (1 H, dd, $J$ 14.4 and $6.3 \mathrm{~Hz}), 1.45$ (1 H, d, $J 14.1 \mathrm{~Hz}), 1.40-1.10(4 \mathrm{H}, \mathrm{m}), 1.10(3 \mathrm{H}, \mathrm{s})$ and $0.99(3 \mathrm{H}, \mathrm{s})$ [2 x tert- $\left.\mathrm{CH}_{3}\right], 0.95-0.85(2 \mathrm{H}, \mathrm{m}), 0.89(3 \mathrm{H}, \mathrm{d}, J 6.3 \mathrm{~Hz})$ and $0.83(3 \mathrm{H}, \mathrm{d}, J 6.3 \mathrm{~Hz})\left[\mathrm{CH}\left(\mathrm{CH}_{3}\right)_{2}\right] .{ }^{13} \mathrm{C}$ NMR (75 MHz, $\left.\mathrm{CDCl}_{3}, \mathrm{DEPT}\right): \delta 87.9(\mathrm{CH}, \mathrm{CHOMs}), 47.8\left(\mathrm{CH}_{2}, \mathrm{C}-5\right), 45.6(\mathrm{CH}), 44.0(\mathrm{CH})$, 43.0 (C, C-3), $39.2\left(\mathrm{CH}_{2}\right), 38.6$ (C, C-6), $38.1\left(\mathrm{CH}_{3}, \mathrm{OSO}_{2} \mathrm{CH}_{3}\right), 35.6\left(\mathrm{CH}_{2}\right), 31.9(\mathrm{CH}), 27.1(\mathrm{CH})$, $26.5\left(\mathrm{CH}_{3}\right), 24.3\left(\mathrm{CH}_{3}\right), 22.6\left(\mathrm{CH}_{2}, \mathrm{C}-8\right), 21.1\left(\mathrm{CH}_{3}\right), 21.0\left(\mathrm{CH}_{3}\right)$. Mass: m/z $205(\mathrm{M}-\mathrm{OMs}, 26 \%)$, 204 (100), 161 (62), 119 (31), 107 (40), 105 (37), 93 (36). Anal.: For $\mathrm{C}_{16} \mathrm{H}_{28} \mathrm{O}_{3} \mathrm{~S}$, Calcd.: C, 63.96; H, 9.39. Found: C, 64.19; H, 9.76\%.

(-)-(1S,3R,4R,6R,7R,9S)-4-Thiocyanatoneopupukeanane (6). A solution of the mesylate 21 (25 mg, $0.08 \mathrm{mmol}$ ) and potassium thiocyanate $(50 \mathrm{mg}, 0.51 \mathrm{mmol}$ ) in acetone $(1 \mathrm{ml})$ was placed in a Carius tube and heated to $80{ }^{\circ} \mathrm{C}$ for 5 days. The reaction mixture was then cooled, diluted with $\mathrm{CH}_{2} \mathrm{Cl}_{2}(10 \mathrm{ml})$, washed with water and brine, and dried $\left(\mathrm{Na}_{2} \mathrm{SO}_{4}\right)$. Evaporation of the solvent and purification of the residue on a silica gel column using ethyl acetate-hexane (1:40) as eluent furnished 4-thiocyanatoneopupukeanane 6 (6 mg, 27\%) as oil. The synthetic sample exhibited spectral data identical to that of the natural product reported ${ }^{3}$ by Scheuer and Higa. $[\alpha]_{D}^{28}:-117.6$ (c 1.08, $\mathrm{CHCl}_{3}$ ). IR (neat): $v_{\max } / \mathrm{cm}^{-1} 2160 .{ }^{1} \mathrm{H} \mathrm{NMR}$ (300 MHz, $\mathrm{CDCl}_{3}$ ): $\delta 3.47(1 \mathrm{H}$, dd, $J 8.4$ and 3.3 $\mathrm{Hz}, \mathrm{H}-4), 2.24$ (1 H, dd, $J 15.3$ and $8.1 \mathrm{~Hz}$ ), 1.76 (1 H, ddd, $J$ 14.4, 10.2 and $4.5 \mathrm{~Hz}$ ), 1.70-1.60 (1 H, m), 1.68 (1 H, dd, $J 15.3$ and $3.3 \mathrm{~Hz}), 1.50-1.10(7 \mathrm{H}, \mathrm{m}), 1.21(3 \mathrm{H}, \mathrm{s})$ and $1.05(3 \mathrm{H}, \mathrm{s})[2 \mathrm{x}$ tert- $\left.\mathrm{CH}_{3}\right], 0.90-0.80(1 \mathrm{H}, \mathrm{m}), 0.90(3 \mathrm{H}, \mathrm{d}, J 6.6 \mathrm{~Hz})$ and $0.81(3 \mathrm{H}, \mathrm{d}, J 6.6 \mathrm{~Hz})\left[\mathrm{CH}\left(\mathrm{CH}_{3}\right)_{2}\right] .{ }^{13} \mathrm{C}$ NMR (75 MHz, CDCl $)$ ): $\delta 113.8$ (C, SCN), 60.1 (CH, CHSCN), $50.5\left(\mathrm{CH}_{2}, \mathrm{C}-5\right), 45.7\left(\mathrm{CH}_{2}\right), 45.1$ (CH), 44.8 (C, C-3), $43.1(\mathrm{CH}), 39.1$ (C, C-6), $37.8\left(\mathrm{CH}_{2}\right), 31.8(\mathrm{CH}), 27.8(\mathrm{CH}), 26.7\left(\mathrm{CH}_{3}\right), 24.0$ $\left(\mathrm{CH}_{3}\right), 22.4\left(\mathrm{CH}_{2}, \mathrm{C}-8\right), 21.0$ (2 C, $\left.\mathrm{CH}_{3}\right)$. Mass: m/z 205 (M-SCN, $\left.\mathrm{C}_{15} \mathrm{H}_{25}, 100 \%\right), 149$ (20), 107 
(32), 93 (23). Further elution of the column with ethyl acetate-hexane (1:10) furnished the unreacted starting mesylate 21 (15 mg, 60\%).

\section{Acknowledgements}

We thank the Department of Science and Technology, New Delhi for the financial support and the Council of Scientific and Industrial Research, New Delhi for the award of a research fellowship to SJG.

\section{References and Notes}

1. (a) Burreson, B. J.; Scheuer, P. J.; Finer, J.; Clardy, J. J. Am. Chem. Soc. 1975, 97, 4763. (b) Hagadone, M. R.; Burreson, B. J.; Scheuer, P. J.; Finer, J. S.; Clardy, J. Helv. Chim. Acta 1979, 62, 2484.

2. Karuso, P.; Poiner, A.; Scheuer, P. J. J. Org. Chem. 1989, 54, 2095.

3. Pham, A. T.; Ichiba, T.; Yoshida, W. Y.; Scheuer, P. J.; Uchida, T.; Tanaka, J. -i.; Higa, T. Tetrahedron Lett. 1991, 32, 4843.

4. He, H. -y.; Salva, J.; Catalos, R. F.; Faulkner, D. J. J. Org. Chem. 1992, 57, 3191.

5. Synthesis of 2-isocyanopupukeanane and pupukean-2-ones: (a) Corey, E. J.; Ishiguro, M. Tetrahedron Lett. 1979, 2745. (b) Frater, G.; Wenger, J. Helv. Chim. Acta 1984, 67, 1702. (c) Chang, N. -C.; Chang, C. -K. J. Org. Chem. 1996, 61, 4967. (d) Kaliappan, K.; Subba Rao, G. S. R. Tetrahedron Lett. 1997, 38, 2185. (e) Kaliappan, K.; Subba Rao, G. S. R. J. Chem. Soc., Perkin Trans. 1 1997, 3387. (f) Kaliappan, K.; Subba Rao, G. S. R. J. Chem. Soc., Perkin Trans. 1 1997, 3393. (g) Srikrishna, A.; Vijaykumar, D.; Sharma, G. V. R. Tetrahedron Lett. 1997, 38, 2003. (h) Srikrishna, A.; Vijaykumar, D.; Sharma, G. V. R. Indian J. Chem. 1999, 38B, 766. (i) Biju, P. J.; Subba Rao, G. S. R. Tetrahedron Lett. 1999, 40, 181. (j) Biju, P. J.; Kaliappan, K.; Laxmisha, M. S.; Subba Rao, G. S. R. J. Chem. Soc., Perkin Trans. 1 2000, 3714. (k) Srikrishna, A.; Kumar, P. R. Indian J. Chem. 2002, 41B, 152. For enantiospecific synthesis of pupukean-2-one, see (k) Srikrishna, A.; Reddy, T. J. J. Chem. Soc., Perkin Trans. 1 1997, 3293. (l) Srikrishna, A.; Reddy, T. J. J. Chem. Soc., Perkin Trans. 1 1998, 2137. (m) Srikrishna, A.; Kumar, P. R.; Gharpure, S. J. Tetrahedron Lett. 2001, 42, 3929.

6. For synthesis of 9-isocyanopupukeanane and pupukean-9-ones: see (a) Corey, E. J.; Behforouz, M.; Ishiguro, M. J. Am. Chem. Soc. 1979, 101, 1608. (b) Yamamoto, H.; Sham, H. L. J. Am. Chem. Soc. 1979, 101, 1609. (c) Schiehser, G. A.; White, J. D. J. Org. Chem. 1980, 45, 1864. (d) Piers, E.; Winter, M. Justus Liebigs Ann. Chem. 1982, 973. (e) Hsieh, S. -L.; Chiu, C. -T.; Chang, N. -C. J. Org. Chem. 1989, 54, 3820. For enantiospecific synthesis of pupukean-9-one, see: (f) Srikrishna, A.; Kumar, P. R. Tetrahedron Lett. 2002, 43, 1109. For enantiospecific synthesis of analogues of pupukean-9-ones, see: (g) Srikrishna, A.; Hemamalini, P.; Sharma, G. 
V. R. Tetrahedron Lett. 1991, 32, 6609. (h) Srikrishna, A.; Hemamalini, P.; Sharma, G. V. R. J. Org. Chem. 1993, 58, 2509. (i) Srikrishna, A.; Danieldoss, S. J. Org. Chem. 1997, 62, 7863.

7. For a preliminary communication, see: Srikrishna, A.; Gharpure, S. J. Tetrahedron Lett. 1999, 40, 1035.

8. To the best of our knowledge, there is no report on the synthesis of neopupukeananes prior to the publication of our results in 1998, (a) Srikrishna, A.; Gharpure, S. J. Chem. Commun.

1998, 1589. For the synthesis of ( \pm )-9-isocyanoneopupukeanane, see: (b) Ho, T. -L.; Jana, G. H. J. Org. Chem. 1999, 64, 8965. For the synthesis of ( \pm )-2-thiocyanatoneopupukeanane, see: (c) Uyehara, T.; Onda, K.; Nozaki, N.; Karikomi, M.; Ueno, M.; Sato, T. Tetrahedron Lett. 2001, 42, 699. For the enantiospecific synthesis of 2-thiocyanatoneopupukeanane, see: (d) Srikrishna, A.; Gharpure, S. J. J. Chem. Soc., Perkin Trans. 1 2000, 3191. For the enantiospecific synthesis of (-)-4-thiocyanatoneopupukeanane, see: (e) Srikrishna, A.; Gharpure, S. J. J. Org. Chem. 2001, 66, 4379.

9. (a) Srikrishna, A.; Reddy, T. J. Indian J. Chem. 1995, 34B, 844. (b) Srikrishna, A.; Vijaykumar, D.; Reddy, T. J. Tetrahedron 1997, 53, 1439. (c) Srikrishna, A.; Reddy, T. J.; Kumar, P. P. Chem. Commun. 1996, 1369. (d) Srikrishna, A.; Kumar, P. P.; Reddy, T. J. Tetrahedron Lett. 1998, 39, 5815. (e) Srikrishna, A.; Reddy, T. J. Tetrahedron 1998, 54, 11517. (f) Srikrishna, A.; Viswajanani, R.; Dinesh, C. J. Chem. Soc., Perkin Trans. 1 2000, 4321. (g) Srikrishna, A.; Gharpure, S. J.; Kumar, P. P. Tetrahedron Lett. 2000, 41, 3177. (h) Srikrishna, A.; Anebouselvy, K.; Reddy, T. J. Tetrahedron Lett. 2000, 41, 6643. (i) Srikrishna, A.; Vijaykumar, D. J. Chem. Soc., Perkin Trans. 1 2000, 2583. (j) Srikrishna, A.; Anebouselvy, K. J. Org. Chem. 2001, 66, 7102. (k) Srikrishna, A.; Reddy, T. J. ARKIVOC 2001, (viii), p 9. (l) Srikrishna, A.; Babu, N. C. Tetrahedron Lett. 2001, 42, 4913. (m) Srikrishna, A.; Reddy, T. J.; Kumar , P. P.; Gharpure, S. J. Indian J. Chem. 2001, 40B, 905. (n) Srikrishna, A.; Anebouselvy, K. Tetrahedron Lett. 2002, 43, 2769. (o) Srikrishna, A.; Anebouselvy, K. Tetrahedron Lett. 2002, 43, 5261.

10. Zhao, R. -B.; Zhao, Y. -F.; Song, G. -Q.; Wu, Y. -L. Tetrahedron Lett. 1990, 31, 3559.

11. In addition to the mesylate, $30 \%$ of a by-product (corresponding chloromethanesulfinate) was also formed. For details and other examples, see: Srikrishna, A.; Gharpure, S. J. Synlett 2000, 1354.

12. (a) Stork, G.; Ficini, J. J. Am. Chem. Soc. 1961, 83, 4678. (b) Burke, S. D.; Grieco, P. A. Org. React. 1979, 26, 361.

13. (a) Norin, T. Acta Chem. Scand. 1963, 17, 738. (b) Dauben, W. G.; Deviny, E. J. J. Org. Chem. 1966, 31, 3794. (c) Dauben, W. G.; Wolf, R. E. J. Org. Chem. 1970, 35, 374. (d) Dauben, W. G.; Wolf, R. E. J. Org. Chem. 1970, 35, 2361. (e) Norin, T. Acta Chem. Scand. 1965, 19, 1289. (f) Srikrishna, A.; Krishnan, K.; Yelamaggad, C. V. Tetrahedron 1992, 48, 9725. (g) Srikrishna, A.; Krishnan, K. J. Org. Chem. 1993, 58, 7751. 